\section{Eating in San Francisco: A Brief Glimpse of the City's Restaurants}

\author{
Richard A. Brody, Nancy Ranney, \\ Philip Siegelman, and \\ Raymond E. Wolfinger ${ }^{1}$
}

\section{Introduction}

The restaurants we mention are a non-random sample of those we have tried and enjoyed. We have tried to cover a wide variety of cuisines but some are omitted. We have oversampled restaurants in the general neighborhood of the Hilton but San Francisco is small and not difficult to get around.

Let's begin with some general pronouncements about eating and drinking in San Francisco: Beef is not the thing to eat here because California beef is inferior to what can be found in Chicago, Kansas City, Atlanta, New York, or Washington. Political scientists who must have a steak should try Alfred's, 886 Broadway (781-7058), Ruth's Chris Steak House, 1700 California (673-0557), or The Palm, 586 Bush (981-1222). All import their beef from other regions.

Local seafood can be excellent when in season. Salmon is best in summer. The justly famous Dungeness crab is out of season in summer and available only frozen - which is to be avoided-or fresh after a long and unbeneficial trip from the Northwest or Alaska. Fresh local shrimp/ prawns are excellent but scarce. Frozen ones are like those everywhere else. If you see "red snapper" on a menu, ask if it is from the Pacific Ocean or the Gulf of Mexico. The latter is the real thing and priced accordingly.

Cabernet Sauvignon, the king of California red wines, is seldom gentle in its youth, which we define as under six years of age. Two fastermaturing alternatives are Merlot, which costs as much as Cabernet, and Zinfandel (red, not white) which costs less. Chardonnay is the queen of California white wines. A cheaper choice for drinking before the food comes and with less-rich dishes is Sauvignon Blanc, also known as Fume Blanc. The Bay Area is a hotbed of boutique breweries, which try to turn out a product with greater flavor and body than ordinary American beers. The best-known example is Anchor Steam Beer. Another stellar product of this movement is Sierra Nevada Pale Ale.

You should always take for granted the need to make reservations. We have indicated the need to do so only in those few instances where the call should be made one to two months in advance. On the other hand, calls the same day may uncover last-minute opportunities.

A word on price. We will use the following code for price range: $\$=$ cheap (less than $\$ 12 /$ person); $\$ \$=$ moderate ( $\$ 12-\$ 25 /$ person); $\$ \$ \$=$ moderately expensive $\mathbf{( \$ 2 5 - \$ 4 0 /}$ person); $\$ \$ \$ \$$ = very expensive (more than $\$ 40 /$ person). Wine is extra.

We will begin with a section on restaurants that can be reached by a ten-minute walk from the Hilton. After this listing, we will give a general description of San Francisco neighborhoods in which one can eat well. Restaurants outside the tenminute radius will be grouped by cuisine with an indication as to their neighborhood. The neighborhoods are good places to stroll and satisfy your desire to make your own discoveries. If you get to a recommended place and it is crowded, scout around.

Downtown/Tenderloin: "Downtown" is really not a neighborhood and the restaurants vary widely as to ethnicity. In the past there were few quality eating places but happily that has changed. The Tenderloin is a seedy area around the Hiltonroughly bounded on the south by Market Street, on the north by O'Farrell, on the east by Taylor, and on the west by Polk. Into this neighborhood have come waves of Southeast Asian refugees. The area still has many of its former inhabitants, who are more into crime and drugs than lemon grass and fish sauce, so do not wander these streets alone! However do not avoid the Tenderloin either since there are excellent restaurants here and they are inexpensive. We will mention some but there are many other good ones.

\section{Downtown and Tenderloin Restaurants}

Harbor Village.

4 Embarcadero Center.

784-8833. \$\$

This has become the Cantonese restaurant in The City. Great view and delicious food. Creative dim sum at lunch. For the quality, it is a very good value. This stretches our definition of "downtown" by five minutes or so.

Dojima-An.

219 O'Farrell Street. \$

Wonderful hand-pulled noodles with all the toppings at bargain prices.

Mela Indian.

417 O'Farrell Street. 778-7171. \$\$

About a block from the Hilton. High quality Punjabi cooking.

New Delhi. 160 Ellis Street. 397-8470. \$-\$\$

Julie Sahni-author of the best Indian cookbook-sings the praises of this new Indian restaurant. It is practically on the doorstep of the Hilton.

Kuleto's. 225 Powell Street. 397-7720. \$\$

A blend of California and Italian food with superb pastas and soups. Two blocks from the Hilton.

Janot's. 44 Campton Place bet. Stockton and Grant. 392-5373. \$\$

A short walk from the Hilton; sophisticated French food and friendly service.

Masa's. 648 Bush Street bet. Powell and Stockton. 989-7154. \$\$\$

This is a real world-class restaurant with prices to match. The $\$ 65 /$ person prix fixe is a bargain when compared with meals of this quality in Paris or New York. Plan way ahead and reserve six weeks in advance.

Corona Bar and Grill. 88 Cyril Magnin Street at Ellis. 392-5500. \$-\$\$ About two blocks from the Hilton, the Corona offers "interpretations", of regional Mexican and southwestern food.

Post Street Bar and Cafe. 632 Post Street bet. Taylor and Leavenworth. 928-2080. \$\$ 
A pleasant, satisfying place; three blocks from the Hilton.

Postrio. 545 Post Street bet. Mason and Taylor. \$\$-\$\$

A very fashionable restaurant serving excellent, mostly American cuisine.

Reserve at least six weeks in advance for dinner; try dropping in for lunch. It is only two blocks from the Hilton.

Tadich's. 240 California Street. 391-2373. \$\$

A favorite fish place for $75+$ years.

Sam's. 374 Bush Street. 421-0594. \$\$ Great fish, seafood and the best veal chop in town. Closed Saturday and Sunday. Reservations only for six or more.

Sears' Fine Food. 439 Powell bet. Post and Sutter. \$

Short walk from the Hilton; it is very popular for breakfast. After $8: 30$ am you may have to wait on the sidewalk.

Cafe Claude. Claude Alley parallel to Kearny bet. Kearny and Grant bet. Bush and Sutter. \$\$

A very pleasant and authentic place with good, light bistro-type lunches and soups. Good selection of French wines by the glass. Crowded at lunch; try it at 11:45.

Le Central. 453 Bush Street (near Kearny). 391-2233. \$\$

A very popular bistro that deserves being crowded.

Chambord. 150 Kearny (corner of Sutter). 434-3688. \$\$

Competent, casual, pleasant French food.

Donatello. 501 Post Street. 441-7182 \$\$ $\$ \$ \$ \$$

Mostly Italian and entirely haute. One of the two best Italian wine lists in The City. Two blocks from the Hilton.

French Room. Clift Hotel. 495 Geary at Taylor. 775-4700. \$\$\$ Traditional "fine dining" of very high quality. Excellent French food and professional service.

Maltese Grill. 20 Annie Street (off New Montgomery, south of Market). 777-1955. \$\$
Mediterranean food, "fun" atmosphere, lots of garlic everywhere.

Pierre at Meridien. 50 Third Street (just south of Market in Le Meridien Hotel). 974-6400. \$\$\$

Swank and elegant are the appropriate adjectives for this French restaurant. A daily prix-fixe tasting menu is carefully prepared and presented.

Vietnam II Seafood. 701 Larkin Street. 885-1274. \$

This may be the best in town. Much more Vietnamese than English is spoken here but the food justifies the effort at communication.

Racha. 771 Ellis Street between Polk and Larkin. 885-0725. \$

Wonderful bargain Thai food near the Hilton.

\section{THE NEIGHBORHOODS}

Chinatown: There are now two Chinese districts in San Francisco, the older one which we will discuss here, still called "Chinatown," and Clement Street which we will cover below. For our purposes, Chinatown is bounded by Sacramento Street on the south, Broadway on the north, Kearny Street on the east and Powell Street on the west. It is very easy to walk from the Hilton to Chinatown. Stockton Street (thru the not-alwayspleasant tunnel) and Grant Avenue (hillier than Stockton) both lead right to it; about a fifteen to twenty minute walk. There are hundreds of places to eat here; we will list a few. Some are quite expensive for Chinese restaurants; most are excellent value. Given the complexity of the cuisine and diversity of style, we will subcategorize Chinese restaurants. Restaurants in Chinatown will be indicated with a bold capital CT at the end of the entry.

North Beach: This used to be the Italian section of The City but is more diverse now. It is still the best place for espresso and pizza (except for Postrio). Columbus Avenue, the main street of the neighborhood, is a pleasant place to walk day or night. For the historically minded, City Lights Bookstore and Vesuvio's Bar-where the early members of the Beat Generation read and drank-are on Columbus Avenue one block south of Broadway. Food-minded persons who are not after Chinese food will turn north at Columbus and Broadway. The coffee bars start at Columbus and Vallejo (the oldest is Cafe Trieste at Vallejo and Grant) and are found along Columbus for about the next ten blocks. We will indicate that a restaurant is in North Beach with a bold capital NB at the end of the entry.

Around the Opera House: One of the newer eating areas of The City is the area around Civic Center and the Opera House. This is just west of the Tenderloin but worlds away socioeconomically. The southern border is Market Street, Larkin Street on the east, Gough [rhymes with cough] Street on the west and Ellis Street on the north. The highest concentration of California cuisine restaurants is found in this area. We will indicate that a restaurant is in the area of the Opera House with a bold capital $\mathbf{O H}$ at the end of the entry.

South of Market [SOMA]: SOMA is a transformed light industrial zone, now home to artists' lofts, factory outlets, and trendy restaurants. Obviously, Market Street is the northern border, 2nd Street ${ }^{2}$ is the eastern border, 11th Street is the western border, and Townsend Street is the southern edge. We will indicate that a restaurant is south of Market with a bold capital SOMA at the end of the entry.

The Mission: This is a city within The City and home to quite an ethnic mix. It is just west of SOMA; south of Market. Primarily Hispanic, it also houses San Francisco's best Italian bakery (Diande's on Mission Street at 24th) and some good Asian and Italian restaurants. The Mission is quite large but for our purposes the key streets are Mission, Valencia and Guerrero and the numbered streets between 16 th and 25 th that cross them. We have no idea how many Mexican, Salvadoran, and Cuban restaurants are in the Mission-dozens certainly; perhaps hundreds-we will name only a few that we frequent. We will also mention some Southeast Asian restaurants in the Mission as well. We will indicate that a restaurant is in the Mission with a bold capital $\mathbf{M}$ at the end of the entry.

Clement Street and Geary Boulevard: This is the western limit of our 
tour of eating areas, reached by cab or by buses that run along Geary Street-one block from the Hilton. This area is now the "second Chinatown." The new has not fully displaced the old; there are Russian restaurants here, alongside nouvelle French and not-so nouvelle French, alongside dozens of excellent Chinese, Cambodian, Thai, Burmese, and Vietnamese restaurants. We will indicate that a restaurant is in this area with a bold capital $\mathbf{C - G}$ at the end of the entry.

The Marina: Contrary to the impression conveyed by coverage of the October 17th earthquake, the Marina is very much in business. This area on the north central edge of The City has lots of good small eating places; it is easily reached by the number 30 Muni bus, which also runs through Chinatown and North Beach-get it at Stockton and Sutter. For our purposes-ignoring the distinction between the Marina and Cow Hollow - the boundaries are Union Street to the south, Chestnut Street to the north, Divisadero to the west and Van Ness Avenue to the east. One cannot characterize the Marina ethnically, it is middle class and upward bound. But with some exceptions the restaurants are now expensive. It has an excellent Italian delicatessen (Lucca, on Chestnut), from which one could produce a superb picnic to eat on the Marina Green-a five minute walk to the north. We will indicate that a restaurant is in this area with a bold capital MAR at the end of the entry.

With all of this talk of neighborhoods some of the places we mention are not in any of these areas, but don't reject them for that reason. The neighborhoods are good to explore. Some are compact-Chinatown, the Marina, and North Beach-others are large-SOMA, Clement Street and the Mission.

\section{THE CUISINES:}

\section{CHINESE}

A. Hunan, Szechuan, Mandarin:

Hunan, [two locations] 853 Kearny Street [CT] and 924 Sansome Street at Vallejo, 956-7727 [only the Sansome Street branch takes reservations] \$

One of the best known Hunan restaurants. An excellent, limited, menu; the Kearny branch is tiny. Try the green onion pancakes.

North China, 2315 Van Ness Avenue at Vallejo. 673-8201. \$

Mandarin and Szechuan food of excellent quality.

The Mandarin, Ghirardelli Square. 673-8812. \$\$

Expensive for a Chinese restaurant. Good food, luxury surroundings, great view.

B: Shanghai. Shanghai cooking is relatively new to San Francisco. It features more seafood and stewed meat than other Chinese cuisines. We will make two recommendations.

House of Nanking, 919 Kearny Street. 421-1429. \$ [CT]

The local restaurant critics are mad for this place and we agree. It is a tiny place but worth the wait.

Wu Kong, One Rincon Center [101 Spear Street]. 957-9300. \$\$ [SOMA] A large Hong Kong import that gets rave reviews and deserves them. From 11:00 am - 2:30 pm it serves dim sum from the menu and from rolling carts. Shanghai and Cantonese dinners from 5:30 - 9:30 pm.

C. Cantonese. Cantonese was the standard Chinese cuisine of San Francisco until the establishment of the Peoples' Republic of China sent Chinese from other regions to Taiwan and the U.S.

Lichee Garden. 1416 Powell Street. 397-2290. \$ (\$ for banquets) [CT]

The banquet meals here are first rate and so is the food ordered from the menu. If you set up a banquet insist on getting advice about the Chineselanguage menus; don't settle for the English-language menus. Try minced squab on lettuce leaves.

Oceans. 726 Chestnut Street. 221-3351. \$ [C-G]

Very good seafood and fish and "special spare-ribs" (i.e., pork chops).

D. Dim Sum (Tea Lunch). This is wonderful food and a great eating experience. Forget menus; the food comes around more or less continually on carts, you pick and choose. Lots of this is wrapped in pastry but unless you really pig out, you'll up for the afternoon panels. A pigout may raise the price above the $\$$. Dim sum is generally available between $10 \mathrm{am}$ and $2 \mathrm{pm}$; the noon hour usually means a wait.

Hong Kong Teahouse. 838 Pacific Avenue. No reservations. \$ [CT]

Wu Kong. One Rincon Center [101 Spear Street]. 957-9300. \$\$ [SOMA]

Harbor Village. 4 Embarcadero Center. 784-8833. \$ [D]

Yank Sing. 427 Battery Street. 3621640. \$(D)

\section{SOUTHEAST ASIAN}

\section{A. Thai.}

Samui Thai. 2414 Lombard Street. 563-4405. \$ [MAR]

First-class Thai food at bargain prices. The appetizers are worth the trip.

Little Thai. 2348 Polk Street near Union. 771-5344. \$

Small neighborhood restaurant with terrific food.

Manora. 1600 Folsom Street. 861-6224. \$ [SOMA] and 3226 Mission Street. 550-0856. \$ [M] A long-term favorite. Creative Thai food.

Khan Toke. 5937 Geary Blvd. at 24th Ave. 885-0725. \$-\$ [C-G] After the review in Gourmet, the prices went up. It is still good value for the cost and an interesting and comfortable restaurant.

\section{B. Cambodian.}

Angkor Wat. 4217 Geary Blvd. 221-7887. \$ [C-G]

One of the first and still very good.

Angkor Palace. 1769 Lombard Street. 931-2830. \$ [MAR]

Every dish is delicious and beautifully presented. The room is comfortable if a bit glaring.

Bayon. 2018 Lombard Street. 922-1400. \$ [MAR] 
Frenchified Cambodian food and Cambodianized French food. What a marriage! It is wonderful and a huge bargain. French set-piece meals under $\$ 10$.

\section{Vietnamese.}

Golden Turtle. 2211 Van Ness Ave. at Washington Street. 441-4419. \$ and 308 th Ave. near Clement. 221-5285. \$ [C-G]

The chef is the sculptor. He creates wonderful food, too.

D. Indian.

Maharani. 1115 Polk at Post [entrance is on Post]. 775-1988. \$-\$\$ The tandoori is great here and so, too, are the curries. If you're really hungry, try the $\$ 18$ / person multicourse dinner.

North India. 3131 Webster Street at Lombard. f931-1556. \$\$ (MAR) Elegant North Indian food (including tandoori dishes) in a comfortable restaurant.

Peacock. 2800 Van Ness Ave. at Lombard. 928-7001. \$\$-\$\$ [MAR] The ambience and the food are upscale and elegant.

Pasand. 1875 Union Street. 922-4498. \$ [MAR]

This is a great Madras (South Indian) restaurant-no tandoor oven here.

\section{ITALIAN}

Buca Giovanni. 800 Greenwich at Columbus. 776-7766. $\$ \$$ (NB)

If you can only fit in one Italian meal in San Francisco, this is the place. Nobody treats rabbit with more respect. The pastas are beyond compare.

Ristorante Milano. 1448 Pacific Ave. bet. Hyde and Larkin. 673-2961. $\$-\$ \$$

An excellent neighborhood Northern Italian restaurant. Regulars line up on the street for this small place. Excellent value.

Acquerello. 1722 Sacramento Street bet. Polk and Van Ness. 567-5432. \$\$-\$\$

Rustic Italian cooking in a small, attractive restaurant. The wine list is one of the great ones. A superb place to celebrate.

Girapolli. 659 Union Street at Columbus. 434-4472. \$ [NB] Chicken as you've never had it before at bargain prices. This is a tiny place that is a real treat. Full meal below $\$ 9$.

Roti. Steuart Street (bet. Mission and Howard.) 495-6500. \$\$ [SOMA]

A new Italian restaurant that specializes in grilled meats and fowl.

Oritalia. 1916 Filmore Street at Pine. 346-1333. \$\$

A blend of Italian and oriental cuisine. The menu offers variety and originality.

\section{Fornaio. 1265 Battery (Levi} Plaza). 986-0100. \$\$

Attractive food in an attractive setting. A bakery, a delicatessen, pizzeria, bar and counter cafe serving Italian regional food influenced by California cuisine.

Tutto Bene. 2080 Van Ness Ave., near Pacific Ave. 673-3500. \$\$

Trendy Italian cooking provides fun and good food in a bright noisy place.

Contadina Trattoria. 1800 Mason Street at Union. 982-5728. \$-\$\$ [NB] A modest charming neighborhood place. Good pasta and salads.

Original Joe's \#2. 2001 Chestnut Street at Fillmore. 346-3233. \$-\$\$ [MAR]

Sit at the counter and watch them cook. Joe's is sort of Italian but with great steaks and a hamburger of startling quality. The \#30 bus takes you to the door.

\section{FRENCH}

L'Avenue. 3854 Geary Blvd. at 3rd Ave. 386-1555. \$\$ [C-G]

Bistro atmosphere and excellent food.

La Folie. 2316 Polk Street bet. Green and Union. 776-5577. \$\$\$

Beautifully presented haute cuisine in pleasant surroundings.

Le Piano Zinc. 708 14th Street, just off Market Street. 431-5266. \$\$\$

Rabbit and venison and sensational appetizers. Pleasing atmosphere and a prix-fixe meal that is an excellent value.

Bistro Clovis. 1596 Market Street at Franklin. 864-0321. \$-\$\$ [OH]

Good food and wonderful wine at reasonable prices.

Cafe Jacqueline. 1454 Grant Avenue. 981-5565. \$\$ [NB]

A small, charming place specializing in souffles. Open only at dinner.

South Park Cafe. 108 South Park bet. 2nd and 3rd Streets. 495-7275. \$\$ [SOMA]

A very hospitable brasserie, six blocks south of Market Street. Tapas are served from 5-7.

\section{MEXICAN, ETC.}

Pancho Villa. 3071 16th Street bet. Mission and Valencia. \$ [M] If there are better burritos and tacos, they haven't come to our attention. Try the carne asada, carnitas, and lengua.

La Taqueria. 2889 Mission bet. 24th and 25th Streets. \$ [M]

Same story as Pancho Villa.

Nicaragua Restaurant. 3015 Mission at Army. 826-3672. \$ [M]

More a dinner place than a taqueria. Excellent value.

\section{CALIFORNIA}

California cuisine emphasizes fresh local ingredients, grilled meats and fish, and minimalism in cooking. The style stems from Chez Panisse in Berkeley but each chef puts her/his stamp on the product. The Corona would fit here; Ya Ya, a blend of California and Middle Eastern, qualifies too.

Hayes Street Grill. 324 Hayes Street. 863-5545. \$\$ [OH]

Some of the best fish in The City. Everything is well handled here. Be prepared for noise.

Gypsy Cafe. 687 McAllister Street at 
Gough. 931-1854. \$\$ [OH]

Fine food and wine at prices below those of other California cuisine restaurants in the area.

Zuni. 1658 Market at Franklin. 552-2522. \$\$\$ [OH]

Creative, informal and crowded. The polenta and risottos are especially good.

Hyde Street Bistro. 1521 Hyde Street. 441-7778. \$\$

Interesting food at the low end of the price range for the quality. Fish and chicken are excellent.

Stars. 150 Redwood Alley at Van Ness. 861-7827. \$\$\$ [OH]

High-tech glamour and very good food. Stars Cafe, at the same location, is less expensive.

Square One. 190 Pacific Avenue at Front. 788-1110. \$\$\$

Very good blend of California, Middle Eastern, Mediterranean, and Latin American approaches to cooking. A real original. About a twentyminute walk from the Hilton.

Greens at Fort Mason. Fort Mason, Bldg. A. 771-6222. \$\$ [MAR] The pinnacle of vegetarian cooking. Reserve well in advance.

YaYa. 397 1/2 Eighth Street. 255-0909. \$-\$\$ [SOMA] Extraordinary blend of California and Middle Eastern cuisines. Chicken, lamb, and outstanding vegetables. A real bargain.

eddie jacks. 1151 Folsom Street. 626-2338. \$-\$\$ [SOMA]

Terrific food.

Fog City Diner. 1300 Battery Street near Lombard. 982-2000. \$\$

Very good California cuisine in an attractive faux diner. A pleasant half-hour walk from the hotel.

City Block. 101 South Park bet. 2nd and 3rd Streets. 543-3663. \$\$

[SOMA]

A fine example of California cooking in a very pleasant place.

\section{A VERY FEW OUT-OF-TOWN RECOMMENDATIONS}

A. Berkeley. Chez Panisse, the font from which California cuisines flow, offers two possibilities: Dinner downstairs in the restaurant, which presently costs $\$ 55$ per person plus wine, tax and tip, should be reserved far in advance. This can be done by writing to 1517 Shattuck Avenue, Berkeley. The lower-priced alternative, Chez Panisse Cafe, takes lunch reservations only on the same day (548-5049); dinner at the Cafe is on a first-come-first-served basis. A muchloved and less famous place for dinner in Berkeley is Lalime's Cafe, 527-9838.

B. Napa Valley. Tra Vigne in St. Helena (AC 707-963-4444) and Mustard's in Yountville (AC 707-944-2424) are excellent.

C. Sonoma County. John Ash \& Co. (AC 707-527-7687) and Restaurant Matisse (AC 707-527-9797), both in Santa Rosa, offer good food in the wine country closer to San Francisco.

\section{Notes}

1. Respectively at Stanford University, the law firm of Hancock, Rothert \& Bunshoft, San Francisco State University, and the University of California, Berkeley.

2. Do not be confused: In San Francisco numbered streets (e.g., 2nd, 1st) are south of Market Street and numbered avenues (e.g., 3rd Ave.) are in the western part of The City. To add to the fun some numbered streets cross each other; to our knowledge, no numbered avenues intersect. While we're at it, since

Market Street crosses The City at an angle and since north-south streets begin their numbering at Market Street, the same street addresses on two parallel north-south streets will not be at the same east-west street. Don't rely on addresses, ask for the names of the cross streets.

\section{APSA Annual Meeting Short Course}

Using the American Government Poli-Ware Simulations in the Classroom

Wednesday, August 29, 9:30-4:00

Stephen Frantzich, Professor of Political Science at the U.S. Naval Academy, has created the first set of six microcomputer decision-making simulations to be distributed by the Poli-Ware Program of the American Political Science Association. They cover a broad range of topics applicable for basic American Government and to upper level courses. The simulations include:

Political Campaigning

Legislative Coalition Building

Political Redistricting

Presidential Popularity

Judicial Process

Public Opinion Polling

In the short course, Professor Frantzich will introduce participants to the process of simulation development and classroom use. There will be an opportunity for "hands on" use of the simulations and a sharing of participant's experiences.

\section{Topics to be Covered:}

- The rationale for using computer simulations to teach American Government

- Overcoming the logistical hurdles

- Integrating computer simulations into the classroom

- Evaluating student use of computer simulations

- The underlying rationale of the American government simulations

- Designing your own simulations

Supported by a grant from IBM. To register contact APSA.

\section{Placement Service Set for Meeting}

The first step in the academic job search begins with the Annual Meeting Placement Service which will be available again at the 1990 Annual Meeting.

The Service allows employers to review the vitae of job applicants and to interview them at the Annual Meeting. Also, applicants can review the list of positions which are open in their respective fields and can apply for positions in which they are interested.

The Placement Service will be open August 30 to September 2 and will be in the San Francisco Hilton.

To participate in the Service, APSA members are urged to register prior to the opening of the Annual Meeting. Placement registration forms are available in this issue of $P S$ and in the APSA's Personnel Service Newsletter. 